\title{
A Context for Professional Learning: Teacher Candidates in Intergenerational Literature Circles
}

\author{
Lynn Lemisko \\ University of Saskatchewan \\ Marg Epp \\ Prairie Spirit School Division, Saskatchewan
}

\begin{abstract}
Our findings indicate that intergenerational literature circles were sites where multi-layered learning took place for teacher candidates. These adult learners developed a deeper understanding of and how children read, learn concepts and respond to text and they enhanced their understandings of multiple perspectives. Teacher candidates indicated that co-learning in the context of a literature circle helped them in their transformation into professional teachers as they experienced and reflected on learners, learning and teaching/learning strategies. Many revised their definitions of 'teacher' as a result of their experiences in intergenerational literature circles.
\end{abstract}

Key Words: teacher education; co-learning; learning contexts; discourse communities.

Lynn Lemisko is an assistant professor of Curriculum Studies at the University of Saskatchewan, teaching social studies methods at the undergraduate level. Her areas of research include teacher education, history of education and citizenship education. Email: lynn.lemisko@usask.ca

Marg Epp is a Learning Support Facilitator in Prairie Spirit School Division. She has 20 years of experience teaching K-6 and undergraduate classes in the area of English Language Arts. Her areas of research interest include literacy, comprehension and constructivist learning approaches.

Brock Education, Volume 18, No. 2, Spring 2009, 66-80. 


\section{A Context for Professional Learning: Teacher Candidates in Intergenerational Literature Circles}

One aspect of our research investigated intergenerational literature circles as pedagogical locations where teacher candidates might become more deeply aware of themselves as colearners/facilitators and as future teachers of young learners. In our multi-layered project, we explored intergenerational literature circles as discourse communities (a) that might be an effective integrated approach to social studies concept development, (b) that would provide a context to assist teacher candidates in becoming more deeply aware of themselves as learners and as future teachers of young learners, and (c) where school-age students could be empowered as they assume an equal role with adult co-learners. Questions we addressed include:

1. What is the relationship between personal reading and teaching and learning?

2. Are intergenerational literature circles effective in exploring diverse perspectives?

3. Are intergenerational literature circles effective in developing more complex and diverse understanding of concepts?

4. Are intergenerational literature circles effective in empowering students?

5. Are intergenerational literature circles effective in assisting teacher candidates in understanding the complexities of their role as professional teachers?

For the purposes of this we focus on the last question: Are intergenerational literature circles effective in assisting teacher candidates in understanding the complexities of their role as professional teachers? We examined, in particular, the efficacy of intergenerational literature circles as an approach to assist teacher candidates in enhancing their understandings of: (a) young learners and their ways of thinking; (b) the processes and strategies of teaching, learning, reading, responding and concept development;(c) diversity and multiple perspectives; and (d) challenges to particular traditional/status quo definitions of 'teacher'.

Our findings indicate that intergenerational literature circles were contexts in which multi-layered learning took place for teacher candidates. These adult learners developed a deeper understanding of how children read, learn concepts and respond to text and teacher candidates also enhanced their understandings of multiple perspectives. Participants generally indicated that they learned more about the act/practice of teaching itself and many found that intergenerational literature circles became the venue through which their definitions of 'teacher' were revised or reformulated.

\section{Related Literature/Theoretical Framework}

Research investigating literature circles and collaborative talk, proliferating since the early 1990s (e.g., Commeyras, Bisplinghoff, and Olson, 2003; Daniels, 2002; Alvermann, et al. 1996; Almasi, McKeown \& Beck, 1996; Langer, 1995; and Wells, 1994), has particularly explored the advantages of engagement in literature circles for grade-school learners. Literature circles provide the context in which the epistemic mode of engagement with text can be elicited (Wells, 1994) as well as the place and space where students can use and practice the personal and heuristic functions of language (Halliday, 1973). Schmidt and Pailliotet (2001) investigated the influence of children's literature on children's attitudes, values and beliefs and how literature is a means of children coming to understand the stories of others. Literature circles can be considered a physical and social location (or context) in which talk should be considered the foundation of 
literacy and conversation the key to comprehension. It is through interaction with others that students develop the ability to construct and communicate meaning (Daniels, 2002).

In comparison, there have been only a handful of studies exploring the benefits of literature circles for teacher candidates in their professional development. For example, Asselin (2000) examined how engagement in peer-based literature circles effected the assumptions about literature and reading held by a group of teacher candidates, while Schick and Hurren (2003) investigated the role of narrative in teaching social studies by engaging teacher candidates in book clubs where members discussed auto-biographies, memoirs and historical fiction. One study (Finke \& Edwards, 1997) investigated literature circles as a site where school-age children worked together with teacher candidates as co-learners. This study revealed that grade four and five students were effective in demonstrating to teacher candidates the processes young learners use when constructing meaning from reading. However, there have been studies in teacher education (e.g., Cochran-Smith \& Lytle, 1999) which indicate that learning experiences for becoming teachers need a design that enhances their understanding of teaching as a "complex and multifaceted intellectual, creative, decision-making activity" (Schulz, 2005, p. 149). We speculated that intergenerational literature circles could provide this type of experience and we believe that our study contributes to scholarship by exploring the efficacy of literature circles in assisting teacher candidates develop their understandings of students, learning processes, diverse perspectives and the complexity of teaching roles.

Central to our approach is a theory arising out of a relatively new set of ideas about cognition and learning, labeled the 'situative perspective'(Putnam \& Borko, 2000, Greeno, 1997; Greeno, Collins, \& Resnick,1996, Lave \& Wenger 1991). Three main ideas underpin this way of thinking: that cognition and learning are (a) situated in particular contexts; (b) social in nature; and (c) distributed across people, resources and tools (Putnam \& Borko, 2000). Situative theorists (Brown, Collins, \& Duguid, 1989; Lave \& Wenger, 1991) take the position that knowing and learning are not individualistic functions of the human mind nor based purely on individual experience. They argue, rather, that cognition takes place within particular physical and social contexts which deeply influence how and what an individual learns - that what we know, how we know it, and how we express ideas, are products of interactions within groups of people, or within discourse communities (Fish, 1980; Resnick, 1991; Putnam \& Borko, 2000). According to Putnam and Borko (2000), “...discourse communities provide the cognitive toolsideas, theories, and concepts - that individuals appropriate as their own through their personal efforts to make sense of experiences" (p. 5). In discourse communities, cognition is distributed, because it is "stretched over" (Lave, 1988), or shared, among participants who engage in collaborative meaning-making conversations about text and other artifacts.

This perspective argues strongly for the notion that learning activities must be 'authentic' - that is, that learning activities should share contextual features with the 'real life situation' for which the learner is being prepared. This supports the notion that teacher education should be situated within classrooms, however, the situative perspective also helps us see why learning in real life classrooms can be a powerful tool for reinforcing 'traditional' or status quo approaches to teaching, because of the strength of existing schooling culture. Putnam and Borko (2000) suggest that if educational reformers want teachers to think in new ways, "it may be important to have them experience learning in different settings" (p. 6).

We posit that an intergenerational literature circle is a type of discourse community that provides a different setting, or context, within which teacher candidates could develop new ways 
of thinking. Because they would engage primarily with children as co-learners in literature circles, we imagined that teacher candidates could learn new ways of thinking about young learners, learning processes, diverse perspectives and the complexities of their role as professional teachers.

\section{Methods for Gathering and Analyzing Data}

To explore the effectiveness of intergenerational literature circles, we arranged opportunities for cohorts of teacher candidates, enrolled in a Social Studies method's class, to visit classrooms where they participated in literature circles with young learners. The classroom visits took place over a three year period and involved two different cohorts of teacher candidates per year.

Teacher candidates participated as co-learners with grade school students in the literature circle context and all participants explored social studies concepts using contemporary and historical fiction. To create a comfortable environment for all participants, the intergenerational literature circles were composed of a fewer or equal number of teacher candidates as compared to gradeschool students.

In preparation for their field experiences, teacher candidates were coached about their role as co-learners. It was suggested that young learners not be treated as 'peers' or 'buddies', but that teacher candidates must work with students and listen to them. Teacher candidates were advised that they should behave with young learners as they would when working to accomplish group tasks with adult classmates.

During the first year of the project teacher candidates visited a grade six classroom where they participated with students in intergenerational literature circles. The first cohort of teacher candidates visited the grade six students five times during the fall term. All participants read and discussed the same contemporary fiction novel (Peacekeepers by Dianne Linden). The second cohort visited seven times in the winter term and each literature circle group read and discussed a different historical fiction novel related to the theme 'diversity' (Across the Steel River by Ted Stenhouse; Morning Girl by Michael Dorris; Behind the Bedroom Wall by Laura Williams; Daniel's Story by Carol Mataas; The Captive by Joyce Hansen; Underground to Canada by Barbara Smucker; Home Child by Barbara Haworth-Attard; The Lights Go On Again by Kit Pearson; Days of Terror by Barbara Smucker)

In the second and third years of the project, teacher candidates visited classrooms five times during each term. In the fall term of the second year, the cohort of teacher candidates was divided between two classrooms. ${ }^{1}$ One group worked with grade five students, reading and discussing a historical fiction novel (Underground to Canada by Barbara Smucker), while the other worked with grade seven students, reading and discussing a contemporary fiction novel (Parvana's Journey by Deborah Ellis). During the winter term of the second year, the cohort of teacher candidates was divided among three classrooms. Two groups worked with two different groups of grade five students at the same school, reading and discussing a contemporary fiction novel (Seedfolks by Paul Fleischman), while the third group of teacher candidates worked with grade five students at a different school, reading and discussing a historical fiction novel (Copper Sunrise by Brian Buchan).

During the third and final year of the project, in the fall term, two groups of teacher candidates worked with two different groups of grade five students at the same school, reading and discussing a contemporary fiction novel (Peacekeepers by Dianne Linden), while the third 
group of teacher candidates worked with grade four students at a different school, reading and discussing a historical fiction novel (Number the Stars by Lois Lowry). During the winter term, two groups of teacher candidates worked with two different groups of grade five students at the same school, while the third group of teacher candidates worked with grade four students at a different school. All teacher candidates and grade school students read and discussed the same historical fiction novel (Copper Sunrise by Brian Buchan).

To address the research questions related to teacher candidate learning, we gathered data from reflective portfolios written by teacher candidates. The portfolios were created as an assignment for their Social Studies methods course. In their portfolio, teacher candidates were required to record observations about students, classroom and literature circle interactions, social studies concepts and strategies and personal learning. Teacher candidates were also expected to record written reflections about what they had observed. The following questions were provided to them to assist in their reflections:

- Did you (and others) gain more knowledge about people, places, issues, and events (social studies concepts \& content) - why/why not?

- What social, communication and thinking skills do you think were used/practiced? Do you think literature circles (and extension activities) are effective ways to learn/practice these skills - why/why not?

- What did you learn about reading (your own and others) and how people respond to text?

- What are you learning about younger learners from the literature circles and activities?

$\circ$ Are they responding to the story in ways that you had predicted? Do you think they are learning the things you predicted they would? Are they highlighting the same issues as you have? (etc.?)

- What are you learning about teaching \& learning from experiences in literature circles?

- What are you learning about yourself [teacher identity] from experiences in literature circles?

Teacher candidates submitted their portfolios for evaluation. Graded portfolios, along with consent forms, were returned to teacher candidates with both a verbal and written invitation to re-submit a copy of their portfolio, stripped of identifying references. Teacher candidates who agreed to re-submit, signed consent forms and submitted these along with their portfolios to a person who was not associated with the project. This person did not pass the portfolios to the researchers until final grades for the methods course had been submitted to the registrar. While one of the researchers was in a position of power as the instructor of potential participants, teacher candidates had full and voluntary control over whether or not they submitted portfolios for use as data.

The data was analyzed using a qualitative analysis approach. Portfolios were read and coded by each researcher to determine patterns and themes in relation to the research questions. A cross comparison of coding and patterns identified by each researcher was done to confirm emerging themes.

\section{Our Description of Literature Circles}

While there are different names to describe this contextual situation, we begin with the idea of 'literature circles' as semi-structured small groups of learners who gather to discuss texts they have read. While some literature circles are more structured, with individual members being 
assigned particular roles (e.g., 'questioner', 'recorder'), we prefer to use a less structured approach so that group members can participate in discussions without constraints that can be imposed when roles are assigned. Through the oral conversations about what they have read, learners construct meaning by retelling events, talking about characters, sequencing events, paraphrasing, making comparisons to their own lives, predicting outcomes, sharing alternate perspectives, and posing questions.

Specifically for this project, all intergenerational literature circle participants were expected, at a minimum, to read the portion of the novel agreed upon and record ideas for discussion. In particular, participants were asked to: (1) mark passages that they found important, puzzling, curious, confusing, unclear, or well written; and (2) record reactions and connections that address questions such as: Did it remind you of past experiences, people, or events in your life? Did it make you think of anything happening in other stories or books or newspapers you have read? Did it make you think of anything happening around the office/school/university or in your community, or on the news?

The intergenerational literature circles became the launching point for other associated learning activities that included researching and representing understandings in multiple formats, and so on. Keeping this idea in mind will be helpful when reading comments made by teacher candidates, as they sometimes refer to activities associated with, but not directly tied to, their literature circle conversations.

\section{Findings and Discussion}

We will share what we have discovered primarily by using the voices of teacher candidates. ${ }^{2}$ To organize the data, we have divided this section into the themes that emerged during data analysis. While examining and analyzing the portfolios, we discovered four categories of information about the effectiveness of intergenerational literature circles in assisting teacher candidates in their transformation into professional teachers, including: what teacher candidates said they learned about learning; what teacher candidates said they learned about learners and multiple perspectives; what teacher candidates said they learned about strategies and resources; and what we, as researchers, discovered about how teacher candidates define teaching.

\section{What teacher candidates said they learned about learning}

Teacher candidates indicated that intergenerational literature circles were powerful contexts in which learning theory was reinforced. Although on-campus course work introduces ideas about the importance of tapping into prior knowledge arising out of individual life experiences, comments made by teacher candidates regarding their literature circle experiences indicate that this idea was not made real for them until they engaged with grade school students. For example, teacher candidates wrote:

*At first I thought that the group was just poor at comprehension in reading because they were making poor predictions that I thought were off topic. This thought soon changed after realizing that the students were placing meaning and importance on different aspects of the novel based on their understanding in relation to their own lives and experiences. Each child experiences different things in life, each situation affecting them in different ways. As a teacher, I need to recognize that each student will be able to relate to the same 
story in different ways. Each individual will place more value on a certain aspect of the story more than another.

** Before I thought it was all about different levels of learning. Now I think it's all about life experiences and how the stages in our lives help us to experience books. I still believe that we need to view learning through a child['s] experiences. It is only through this that we begin to grasp what children need from us as teachers.

Teacher candidates indicated that intergenerational literature circles were a discourse community through which they came to understand more profoundly how conversations deepen comprehension. They wrote about how they came to understand that talking about personal experiences - connecting 'real life' and prior knowledge to issues being discussed - was vital for building deeper understanding for both adults and children. In addition, they commented on the notion that listening is as important as talking:

*While participating in the literature circles I also realized how a lot of the conversations that we were having would stray away from the book and end up with the children sharing personal experiences. I believe this is how they were internalizing what they were reading and relating it to their own personal experiences. I had never really seen the connection before but now I see what Ketch (2005) means when she said that conversations allow us to make sense of who we are. As an individual I participate in conversations daily. I think that the power of them and the influences they have in my life has really only become apparent to me now. But after making the connection between my personal experience with having conversations and with what Ketch talks about in her article, I am better able to understand why so often, children especially, relate topics of discussion back to their own life experiences.

**The opinions and knowledge that you can gain by listening to others will also give more value and substance to the ideas that you share (when it is your turn, of course). This experience in the school further entrenched in my mind the amount of knowledge one can gain merely by listening to your peers. I think that too many times in school we are encouraged to listen to and learn from our teachers, when we can learn so much more if we also learn to listen to and learn from our peers.

***...I have learned that learning truly is a social process. The students really impressed me with their ability to contribute their own insightful points in discussions based around Copper Sunrise. The students seemed to enjoy asking their own questions, and the students seemed to enjoy taking turns answering those questions. Each question always led to another insightful comment or question and it was awesome to see deep learning taking place.

Intergenerational literature circles provide a context in which teacher candidates discovered that authentic learning involves making choices, taking risks and 'thinking for yourself'. Teacher candidates commented on how their experiences in literature circles helped them discover that learning requires freedom, experimentation, risk-taking and making mistakes: 
*As a teacher I must let students decide their own path to learning. I found myself often trying to guide the students in the direction I wanted them to go at the beginning. I found near the end that when I allowed them to go their own way, even if it was into mistakes, they learned more

**The goal of education is to get the students thinking for themselves and questioning why or how something is the way it is or came to be. Just giving them the answers is doing them an injustice and hindering their ability to think for themselves.

\section{What teacher candidates learned about learners and multiple perspectives}

Intergenerational literature circles were an effective setting which helped teacher candidates discover that they are teaching individuals, not homogeneous groups. They learned that they must take diversity into account by considering learning styles, skills, interests, developmental differences, ways of representing understanding and so on. Again, while these ideas are explored through on-campus study, teacher candidate comments reveal that they learned about learner diversity far more profoundly in the literature circle context. In two examples, different teacher candidates wrote:

*I feel that I have learned a lot as a teacher over the past few weeks working in literature circles. I have seen what a great range of learning abilities, styles, and interests can exist within one small group of children, let alone an entire classroom. It has made me realize that I will have to be very vigilant in attending to the great and varied needs of my students when I have my own classroom.

**Reflecting on my literature circle experience has helped me to carefully consider the type of students I have worked with thus far as a teacher-candidate...I need, at all times, to be aware of who my students are as individuals, so that I can best teach to their needs and abilities and so I can be inclusive of the unique perspectives and varied identities that they bring to the learning process.

Further, intergenerational literature circles assisted teacher candidates in discovering that diversity among learners is to be celebrated rather than feared. They commented on ways in which they saw diversity actually enhancing learning experiences, for example:

*I have also seen, however, how students of varying interests, learning styles and abilities can help one another to build background knowledge, create learning connections, and think critically about material they are studying. This is why literature circles are so wonderful...being useful in almost every subject area and it excites me to think of all the educative possibilities it opens the door to.

In the context of intergenerational literature circles, teacher candidates discovered that their assumptions about young learners are often wrong. They learned that children can be more capable, mature, creative, open, respectful, and accepting than expected.

*Little did I know that I could not prepare for the type of questions that were going to be posed. ...What came up instead were questions of a much deeper level/meaning. 
**We then got talking about Marciella and her baby. This stemmed off into a talk about the girl who dropped off her baby in the cold on someone's doorstep [referring to a local news story]. The students demonstrated empathy by feeling sad for the girl being in that position. They felt that she made the wrong choice and there were more appropriate ways to deal with the situation. Children this age sure can surprise you with the maturity of their logic. I did not expect them to be able to assess this situation so well.

***Being in intergenerational literature circles has taught me that young people see the world differently, and they bring new light to a dark situation. I think that young people think differently than I do, and I can learn a lot from them. I feel the one main thing that intergenerational literature circles has taught me, is that young people are smarter than I thought and they need to be challenged or they will not be interested in paying attention.

In addition, we also discovered that teacher candidates found intergenerational literature circles effective because conversations in this context helped them learn that young people have diverse, complex, and valuable perspectives. Teacher candidates indicated that learning about these multiple perspectives enabled them in better understanding the students with whom they worked and, as an added bonus, they thought that learning about and from multiple perspectives enriched everyone's understanding.

*There was such a range of opinions and feelings on this subject, which was very neat to see. .... I also found interesting, the range of knowledge behind the discussion. They had good reasons to back up their answers and actually thought about the concept, which impressed me.... Seeing how different opinions of children of the same age can have was a good experience for me. It was good to see that I have to be aware of children having opposing views and not trying to persuade anyone to believe my view on a certain topic.

**Without literature circles I don't know if I would have analyzed the novel as much as I did. I also don't think I would see the novel in the same light if it wasn't for having young minds in our group.

***...everyone's understanding of the novel was expanded because each of us could learn from the diverse perspectives of each other.

****When discussing the thoughts and questions, the children got to make meaning of their thoughts by making them more concrete as they discuss. They also get to see things in the text that they may not have found on their own, as everyone interprets information a little bit differently. The idea that everyone interprets information differently held true during this activity. The children were able to answer questions that I had not found answers to myself. I have found that they can be deep readers with little guidance. 
Through conversations in intergenerational literature circles, teacher candidates had a window into students' thinking. These insights assisted teacher candidates in developing their understanding of how learning is enhanced when ideas are explored from differing points of view.

\section{What teacher candidates learned about teaching strategies and resources}

While constructivist teaching strategies and evaluation approaches are endorsed in on-campus courses, teacher candidates are often skeptical about the practical use of such methods. In the context of intergenerational literature circles, teacher candidates discovered that conversation, reflection, knowledge seeking and questioning, constructing knowledge, and collaboration are approaches which promote student engagement and, hence, student learning.

*...using the literature circle method was very eye opening. I see now that having students work in groups to attain knowledge collectively is a great teaching tool. The students were much more excited with these lessons then the one I observed student teaching. The students were much more creative, energetic, and eager to learn using the literature circle as a tool. With lecture they seemed to zone out and lose interest in the lesson very quickly. This is something I want to avoid in my own lessons. I want to try and engage my students in the material and let them think critically about the material I am giving them.

**While I was on my student teaching experience, I experienced a much different teaching/learning style than what was presented at the literature circles. In the literature circles, the students were encouraged to become active and critical members of group discussions, where in the classroom students sat quietly in their desks, researching predetermined question and coloring provincial maps. From what I saw, the students in that classroom were not being challenged to critically examine their environments, or develop skills to examine the past, present, or future. There appeared to be very little opportunity for students in the classroom to sit and discuss their information, probe for deeper meaning, or share their findings with one another. After seeing the benefit of literature circles, which involved amazing conversations and deep questions, I think it would have been of a benefit to allow the students to share their information with one another, rather than perform writing and copying exercises. I feel that a dynamic classroom where students use their imaginations and critical thinking skills to find the answer is a more beneficial exercise than numbly finding and copying answers down into a notebook. When students engage in the lesson being taught, they are more likely to apply and remember the information being taught.

In addition, through intergenerational literature circles, teacher candidates discovered the importance of using an integrated approach - that is, the fusion of subject areas.

* The intergenerational literature circle helped me learn more about how young learners develop understanding of social studies by creating an awareness of how their cognitive ability and experience base affect their learning. Their ability to make connections and understand concepts is strongly related to their prior knowledge and 
experience. [student] was able to relate to Nell's family situation by relating it to his father working up north and being away for long periods of time. He was also able to make a historical connection from a current event article [teacher] brought into class and the novel. This reinforces how young learners benefit from interrelating subjects and how expanding the boundaries by not teaching subjects in isolation is beneficial for the student.

\section{What we, as researchers, discovered about how teacher candidates define teaching}

We thought that the intergenerational literature circle project would provide good field experience opportunities from which all teacher candidates could garner deeper insights into the process of becoming a professional teacher. However, perhaps more importantly, we hoped that these discourse communities, composed of adults and children participating together, would provide the place and space where teacher candidates could begin to see themselves as professional teachers who are co-learners, facilitators and mentors rather than simply transmitters of information.

Based on the data, it became clear to us that some teacher candidates struggled with preconceived definitions of teacher as 'sage on the stage'. We learned that for some, there remained a clear separation between 'teacher' (talker, giver of information, director, authority) and 'co-learner/facilitator'. The degree of discomfort about their role as co-learners expressed in the following excerpts demonstrates this point:

*Today I felt very comfortable being a co-learner, although, we had more of a teacher role today because we had to explain how to create a bibliography as well as how to write effective jot notes. We also had to demonstrate for the students how to change information into their own words. Today we were a little clearer on our role and this made it a good day.

**Today was a good day for being a co-learner because it was mostly a brainstorming day. Our role for today was very clear and we knew exactly how to help the students. I find that the day always runs better if we have direct instruction on what to do. This helps eliminate any confusion about our role.

***I enjoyed moving to the research portion because I felt more confident of my position and what I was supposed to be doing. I felt that I could be a benefit to the student I was working with.

****I feel that I had a better understanding of what I was supposed to do. I felt useful in helping the student I was working with to find the proper terms to use in order to find the information he was looking for on the internet. I did not allow the student to draw me into doing the work for him.

These people drew clear distinctions between the role of teacher and the roles of colearner and facilitator - roles with which they were uncomfortable because they perceived these 
as too fluid and lacking in specific direction. It seems that these teacher candidates think teaching mainly involves transmission, direction-giving, explaining, intervention, and making decisions for learners. For these people, 'to teach' does not, necessarily, include 'to learn'

By contrast, we did learn that for many teacher candidates the experience in intergenerational literature circles helped them define, or re-define, teaching and 'teacher'. These people's comments showed them coming to believe there was no separation between being teacher, listener, organizer, guider, facilitator, and learner. For them, 'to teach' necessarily includes 'to learn'.

*We also must recognize that we are all teachers and we are all learners and this type of experience helps us come to grasp with this concept. In their own little ways [student] and [student] taught me about life and myself, they also opened my eyes to different things I will need to work on as a future teacher and as a human being.

**It was interesting for me to see that the teacher does not have to have all the answers. When given the opportunity, students can be great problem solvers, and come up with ideas that I would not have thought of as options.

***The literature circle has also taught me not to react so fast, and to let students share their thoughts before assuming that they are off task...I have come to understand my identity, and who I am more. I think that the more aware we are of who we are, and what factors contribute to our identity, the more we understand ourselves and the world around us.

We also learned that through intergenerational literature circles many teacher candidates discovered that teaching is about relationships and the gradual release of responsibility.

*I think the biggest thing to remember is that teaching is our job and therefore we are getting paid to pay attention to children and talk with them. It is our job to care, it shouldn't be a forced feeling, sure there is not always enough time in a day to have a one-on-one personal conversation with every student in the class, but we do teach for more than one day. As teachers if we dread having to talk with our students and listen to their "underdeveloped" thoughts then I believe we are in the wrong profession. Teaching is a lot like Social Studies, we can take things from the past and look at how things are going and decide where we want to be. Hearing the "underdeveloped" thoughts of children and watching them grow to more and more developed thoughts over time is what teaching is all about, it's the learning process.... And caring relationships are being able to sit down with your students and have conversations with them, allowing them to make sense of the world around them and have the assurance that they are not alone, and that asking questions is a good thing.

\section{Conclusion}

Our findings indicate that intergenerational literature circles were contexts in which multilayered learning did take place for teacher candidates. In providing a context for epistemic 
modes of engagement (Wells, 1994), literature circles provided the place and space for teacher candidates to work in a discourse community with young people. Challenged to use a set of cognitive tools within a discourse community composed of both adults and children, the teacher candidates' personal efforts to make sense of experiences (Putnam \& Borko, 2000, p. 5), generally appear to have helped them develop deeper understanding of teaching as complex, creative and multi-faceted (Schulz, 2005). These adult learners developed a deeper understanding of learners and learning and they enhanced their understandings of multiple perspectives. Participants generally indicated that they learned more about the act/practice of teaching itself and many found that intergenerational literature circles became the venue through which they revised their definitions of 'teacher' and teaching. We supposed that intergenerational literature circles could provide a 'situated' learning experience in a context where teacher candidates could develop new ways of thinking. We think our findings indicate that many of them did.

As researchers and teacher educators, we have several lingering questions - for example:

1. Will those teacher candidates who redefined 'teacher' and teaching carry these ideas into their practice in the long run?

2. How can we best mentor and support these teacher candidates in sustaining the enthusiasm and belief that all children are capable when they enter environments where change is not always embraced?

3. How might we support in-service teachers in their transformation into lifelong learners?

4. Would other kinds of configurations of literature circles provide similar kinds of potentially transformative learning experiences for teacher candidates (e.g., discourse communities involving teacher candidates and seniors from the community, or teacher candidates and aboriginal members of the community)?

\section{Wrapping Up}

We found that the intergenerational literature project was a learning experience for us, too. Reflecting upon what we witnessed as the project unfolded and upon the direct feedback offered by teacher candidates during and after their experiences in the learning circles has pointed out the power of situated learning. We became poignantly aware of the challenges faced by preservice teachers as they grappled with cognitive dissonances arising from the culture clash between traditional views of teacher, teaching and schooling and ideas about teachers as colearners and mentors. We learned that if teacher educators are aiming to support transformational teaching and learning, we must carefully consider the contextual features of the learning opportunities we offer. Overall, we discovered that intergenerational literature circles are communities where school-age children, teacher candidates and teacher educators have the opportunity to observe, engage and learn together - a powerful combination.

\section{Acknowledgement}

This research was supported by a three-year grant from the Dr. Stirling McDowell Foundation for Research into Teaching. 


\section{Notes}

${ }^{1}$ Originally the project was designed to have teacher candidates visit the classroom of one grade six teacher. During the second year of the project, the grade six teacher took up a new position as Learning Support Facilitator in her school division, so visits were arranged in which the cohorts of teacher candidates worked with more than one teacher and group of students.

${ }^{2}$ A series of asterisks in the following sections denotes different teacher candidate voices.

\section{References}

Almasi, McKeown \& Beck, 1996). The nature of engaged reading in classroom discussions of literature. Journal of Literacy Research, 28(1), 107-146.

Alvermann, D., Young, J.P., Weaver, D., Hinchman, K.A., Moore, D.W., Phelps, S.F., Thrash, E. C. \& Zalewski, P. (1996). Middle and high school students' perceptions of how they experience text-based discussions: A multicase study. Reading Research Quarterly, 31, 244-267.

Asselin, M. (2000). Confronting assumptions: Preservice teachers' beliefs about reading and literature. Reading Psychology,21(31), 31-55.

Brown, J. S., Collins, A., \& Duguid, P. (1989). Situated cognition and the culture of learning. Educational Researcher, 18(1), 32-42.

Cochran-Smith, M. \& Lytle, S. (1999). The teacher research movement: A decade later. Educational Researcher, 28(7), 15-25.

Commeyras, Bisplinghoff \& Olson (2003). Teachers as readers: Perspectives on the importance of reading in teachers' classrooms and lives. Newark, DL: International Reading Association.

Daniels, H. (2002). Literature circles: Voice and choice in book clubs and reading groups. Portland, ME: Stenhouse Publishers.

Daniels, H. \& Steineke, N. (2004). Mini-lessons for literature circles. Portsmouth, NH: Heinemann.

Finke, J. \& Edwards, B. (1997). Teacher education students' insights from intergenerational literature circles. Journal of Teacher Education, 48(5), 367-379. 
Fish, S. (1980). Is there a text in this class? The authority of interpretive communities. Cambridge, MA: Harvard University Press.

Greeno, J. G. (1997). On claims that answer the wrong questions. Educational Researcher, 26(1), 5-17.

Greeno, J. G., Collins, A. M., \& Resnick, L. B. (1996). Cognition and learning. In D. Berliner \& R. Calfee (Eds.), Handbook of educational psychology (pp. 15-46). New York: Macmillan.

Halliday, M.A.K. (1973). Explorations in the functions of language. London: Edward Arnold. Ketch, A. (2005). Conversation: The comprehension connection. The Reading Teacher, 59(1), $8-13$.

Langer, J.A. (1995). Envisioning literature: Literary understanding and literature instruction. NY: Teachers College Press.

Lave, J. and Wenger, E. (1991) Situated learning. Legitimate peripheral participation, Cambridge: University of Cambridge Press.

Lave, J. (1988). Cognition in practice: Mind, mathematics and culture in everyday life. Cambridge: Cambridge University Press.

Putnam, R.T. \& Borko, H.A. (2000). What do new views of knowledge and thinking have to say about research on teacher learning? Educational Researcher, 29(1), 4-15.

Resnick, L. B. (1991). Shared cognition: Thinking as social practice. In L. B. Resnick, J. M. Levine, \& S. D. Teasley (Eds.), Perspectives on socially shared cognition (pp. 1-20). Washington, DC: American Psychological Association

Schick, C. \& Hurren, W. (2003). Reading autobiographies, memoirs, and fictional accounts in the classroom: Is it social studies? Canadian Social Studies, 37(2). Retrieved December 2003, from www.quasar.ualberta.ca/css

Schultz, R. (2005). The practicum: More than practice. Canadian Journal of Education, 28(1 \& 2), 147-167.

Schmidt, P. \& Pailliotet, A. (2001). Exploring values through literature, multimedia, and literary events: Making connections. Newark, DL: International Reading Association.

Wells, G. (1994) Changing schools from within: Creating communities of inquiry. Toronto: OISE Press. 